\title{
Analysis of the tourists' motivation for staying in cities: The case study of the City of Belgrade
}

\section{Анализа мотивације туриста за боравак у градовима: Студија случаја града Београда}

\author{
Milena Podovac ${ }^{*}$ \\ University of Kragujevac, Faculty of Hotel Management and Tourism in Vrnjačka Banja, Republic of Serbia, \\ milena.podovac@kg.ac.rs
}

\begin{abstract}
This paper presents the results of research on the tourists' motivation for staying in the City of Belgrade. The purpose of this paper is to identify the motives for which tourists usually stay in Belgrade and to examine the existence of statistically significant differences between the motives of tourists depending on their sociodemographic characteristics (gender, age, education and origin). The research sample included 250 respondents who had stayed in Belgrade. Belgrade is the most visited destination of urban tourism thanks to the quality and diversity of tourist offer, which can satisfy different motives of tourists. In order to collect primary data, a survey method was applied while descriptive statistical analysis, t-test of independent samples and one-factor analysis of variance (ANOVA) were used to process the collected data. The research findings indicate that the largest number of respondents stayed in Belgrade due to: business reasons, scientific conferences, visits to relatives and/or friends, sightseeing of the city and nightlife. Based on the theoretical analysis and results of empirical research, the recommendations for future research were also presented in the paper.
\end{abstract}

Keywords: motivation, cities, socio-demographic characteristics, tourists, Belgrade.

JEL classification: L83, Z32

Сажетак: У овом раду су приказани резултати истраживања мотивације туриста за боравак у граду Београду. Сврха овог рада је да идентификује мотиве због којих туристи најчешће бораве у Београду и да испита постојање статистички значајних разлика између мотива туриста у зависности од њихових социодемографских карактеристика (пол, старост, образовање и порекло). Узорак истраживања обухватио је 250 испитаника који су боравили у граду Београду. Град Београд је најпосећенија дестинација градског туризма захваљујући квалитетној и разноврсној туристичкој понуди која може задовољити различите мотиве туриста. У циљу прикупљања примарних података, примењена је метода анкете, док су за обраду прикупљених података коришћени дескриптивна статистичка анализа, т-тест независних узорака и једнофакторска анализа варијансе (ANOVA). Резултати истраживања указују на то да је највећи број испитаника боравио у Београду због: пословних разлога, научних скупова, посета рођацима и/или пријатељима, разгледања града и ноћног живота. На основу теоријске анализе и резултата емпиријског истраживања, у раду су дате препоруке за будућа истраживања.

Кључне речи: мотивација, градови, социо-демографске карактеристике, туристи, Београд. JEЛ класификација: L83, Z32

Corresponding author 


\section{Introduction}

Modern tendencies on the tourist market and individualization of tourist demand have contributed to greater recognition of cities as destinations that are recording increasing number of tourists. The reason for the growing interest of tourists to stay in cities is related to the fact that this type of destination has specific tourist resources that allow the formation of a unique tourist offer. Thus formed tourist offer of cities contributes to their recognizability on the international tourism market, as well as forming a recognizable image and brand which guarantees tourists high quality, and value for money (Podovac et al., 2020). The specificity of the tourism development in cities is reflected in their ability to meet the different needs, preferences and motives of tourists with their unique offer. The tourist offer of cities enables the satisfaction of a larger number of motives for the stay of tourists in cities, as a result of which it is difficult to identify and classify them. Urban tourism is a form of tourism which developed in parallel with mass tourism (Füller \& Michel, 2014), but due to the orientation of tourist demand towards coastal destinations, it has not been in the focus of research for a long time (Pearce, 2001). The tendency of intensive development of urban tourism is conditioned by changes in the needs and desires of tourists as well as the fact that more frequent and shorter travels are significantly more common during the year (Podovac, 2017). In addition to being a type of destination with a multifunctional character, cities are important generators of economic development of the entire economy, having in mind the connection of tourism with other economic activities.

Belgrade stands out from all the cities in the Republic of Serbia according to the level of urban tourism development. As the main administrative, political, economic and cultural centre of the Republic of Serbia, Belgrade is a tourist destination, which is well positioned on the tourist market due to its favourable geostrategic position, natural attractions, rich cultural heritage, events, opportunities for nightlife and shopping as well as due to the existence of modern facilities for organizing business events (Podovac, 2016). Quantitative indicators point to the fact that Belgrade is the most visited city in the Republic of Serbia in terms of the number of tourists as well as in terms of the percentage share of foreign tourists in the total tourist turnover. According to the data of the Statistical Office of the Republic of Serbia (2020), 1,205,183 tourists stayed in Belgrade in 2019, which is $32.6 \%$ of the total tourist turnover of the Republic of Serbia. The percentage share of foreign tourists in the total number of tourist arrivals in Belgrade was $84.8 \%$ in 2019 . Due to the large concentration of foreign tourists in Belgrade throughout the year, this city has built the image of an urban tourism destination on the tourist market. In addition, Belgrade is a destination which, with its complex and diverse offer, can meet different needs and motives of tourists for travel. The purpose of this study is to examine the motives of tourists for staying in Belgrade as well as the existence of statistically significant differences between the motives of tourists depending on their socio-demographic characteristics.

\section{Theoretical background}

Motivation in tourism is a complex but still insufficiently researched field in academic 
circles (Iso-Ahola, 1982: Dann, 1977; Crompton, 1979; Dann, 1981; Yoon \& Uysal, 2005). Motivation in tourism implies the influence of internal reasons and factors that encourage people to travel (Devesa et al., 2010). The multidimensional nature of tourists' motivation to travel and stay in a particular destination is related to the fact that tourists very often have a desire to experience more than one attribute of the place they are staying in (Pyo et al., 1989; Filipović, 2018). Bearing in mind that destinations have different attributes, which are connected in a unique tourist offer, during one travel tourists can satisfy a large number of their travel motives, very often those that are not primary as well. Developing various theories on tourist motivation, authors have sought to identify key factors that drive tourists to travel. Changes in the needs and requirements of tourists indicate the need for continuous research of tourist motivation. Identifying the profiles of potential consumers can play a key role in formation the tourist offer of a particular destination (Tomić et al., 2020). Also, tourism represents one of the most important industries, which is characterized by the need for continuous diversification of products (Lakićević \& Sagić, 2019). In addition to changes in the requirements of tourists, tourism development results in the improvement and enrichment of the destination tourist offer, which may cause the emergence of new motives for travel. The motivation of tourists for staying in cities is specific due to the multifunctional nature of the tourist offer of this type of destination. Given that urban tourism offer includes a variety of resources which are used to develop other forms of tourism in cities, this form of tourism can meet the needs of tourists of different sociodemographic characteristics and travel motives. The city as a tourist destination can also be viewed from the aspect of tourists' perception, as a result of which different cities can be seen in different ways by tourists (Podovac, 2019). A large number of authors have emphasized the importance of researching the motivation of tourists to stay in cities as well as the problems they face in their empirical studies (Jansen-Verbeke, 1986; Blank \& Petkovich, 1987; Page, 1995; Dunne, 2009; Ashworth \& Page, 2011). Analysing the previous theoretical knowledge about urban tourism, Ashworth and Page (2011) point out that research on the motivation of tourists to visit and stay in cities is associated with certain difficulties, which make it difficult to answer the questions: why do tourists visit cities and who are the city tourists?

Urban tourists differ from other types of tourists by place of residence and their motives for staying in the city. Tourists who visit cities very often come from non-urban areas and at the same time engage in very different activities in relation to the local population. In addition, the connection between the length of stay in the city and the motive for the visit is expressed. Tourists who come for sightseeing, tours of cultural and historical heritage sites, events, etc. will stay in the city longer. (Jansen-Verbeke, 1986). Tourists in cities can use a large number of attractions which are offered to them, and it is important for them to have a greater possibility of choice in terms of resources and attractions (Dunne, 2009). The structure of the tourist offer of cities as well as the interconnectedness of other forms of tourism, which are developing in cities with urban tourism, make it difficult to define a unique classification of tourists' motives for staying in cities. One of the first classifications was defined by Blank and Petković (1980), highlighting the following motives: visiting relatives and friends, business reasons, recreation, entertainment and 
sightseeing, private reasons, shopping, and other reasons. A much more extensive classification was defined by Page (1995), emphasizing that the city's attractions are in the focus of tourists' interest: visits to relatives and friends, shopping, conferences and exhibitions, education, events, religious reasons, business reasons, day trips, and culture and heritage. Volume of tourist traffic in cities depends on the attractiveness of cultural and historical monuments, environments, events and other various contents which are concentrated in them (Demirović et al., 2018). Classifications of tourists' motives for staying in cities indicate the ability of this type of destination to meet the needs of different profiles of tourists. In addition, it is important to emphasize the economic importance of urban tourism because it ensures the influx of tourists throughout the year and the economic sustainability of the tourism industry. Dunne et al. (2007) investigated the motivation of tourists for city break travel to Dublin, where they identified escape, socialising, and selfesteem (gift giving) as key push motives for this type of travel. In this study, the authors came to the conclusion that pull factors, which are particularly important in the city break travel decisions, encompass: ease of access and availability of low-cost flights as well as the image of the city as a fun destination, and the hosting of events such as major sports events and concerts. Božić et al. (2017) examined the importance of pull factors for the city of Ljubljana (Slovenia) by ranking them from the most dominant to the least dominant motive. Cultural motives and nightlife stood out as the most common pull motives of tourists staying in Ljubljana, while business and religious motives were ranked the lowest. A similar research was conducted by Todorović and Jovićić (2016), researching the push and pull motives of youths for staying in Belgrade. In this study, the authors concluded that the main push factors are related to the desire of youths to have fun, visit interesting places, escape from everyday routine and feel the excitement. Within this study, it was found that the main pull factors such as contact with the local residents, sightseeing and visiting cultural attractions were rated higher than recreation and engagement in night life.

Analysing tourists' motives for staying in cities, which are cultural/heritage destinations, on the example of Guimarães (Portugal), Remoaldo et al. (2017) come to the conclusion that tourists stay in this type of cities mainly because of: touring, visiting cities in the region, architectural heritage and cultural activities. Another similar study was conducted by López-Guzmán et al. (2018) analysing the motivation, satisfaction and loyalty of tourists staying in the city of Cordoba (Spain). The authors identified the cultural motive as the key reason for tourists' stay in this city, while motives such as gastronomy and the search for pleasure were also expressed. Large number of tourists find motivation for visiting cities in the intangible cultural heritage (Sančanin et al., 2019). Researching the attractiveness of city break travel as a form of urban tourism, Balińska (2020) in her study, based on the research, finds that the main motives for staying in cities are: the desire to escape from everyday life routine, sightseeing and relaxation. Analysing the push and pull motives for staying of domestic and foreign tourists in Novi Sad out of the tourist season, Blešić et al. (2008) conclude that the main push motives are related to business meetings, cooperation and meeting new people and making new contacts, while seminar, congress, course, business, and city atmosphere are identified as the pull motives. The authors also conclude that there is a statistically significant difference between the domestic and foreign tourists' push motivessuch as meeting new culture and meeting new environment, i.e. for 
pull motive arrangement price. In their study, Todorović and Jovićić (2016) conclude that nightlife as a motive for staying in Belgrade is more important for male tourists and that this motive was rated higher by respondents with high school.

\section{Research of methodology}

The questionnaire used for the survey consists of two segments. The first segment of the questionnaire contains questions about basic socio-demographic characteristics of the respondents (gender, age, level of education and origin). The second part of the questionnaire contains the questions which refer to the: length of stay, number of visits, manner of making a decision on the visit and travel organization. This part of the questionnaire also asked about the motive of the respondents' stay in Belgrade, which was defined by an analysis of available scientific literature with the same research subject (Page, 1995; Ashworth \& Page, 2011; Todorović \& Jovičić, 2016; Božić et al., 2017; Ramires et al., 2018; Tournois \& Đeri, 2019; Vujičić et al., 2019). Based on theoretical analysis, 14 different motives for the respondents' stay in Belgrade were defined. This research was conducted in the period from January 2019 to June 2020. The questionnaire was distributed in several ways: by sending a questionnaire to the e-mail addresses of potential respondents, through personal contact, and by distributing the questionnaire by licensed tourist guides to tourists during organized tours of Belgrade. The survey questionnaire was compiled in Serbian and English. The research sample included 250 respondents. The collected data were processed in the statistical package SPSS 26 using certain statistical procedures and techniques: descriptive statistical analysis (frequency and percentages), measures of variability (arithmetic mean and standard deviation), t-test of independent samples, and one-factor analysis of variance (ANOVA). The objectives of the research include defining the socio-demographic profile of tourists staying in Belgrade as well as analysing the existence of statistically significant differences between the motives of tourists' stay in Belgrade depending on their socio-demographic characteristics.

\section{Results and discussion}

132 female respondents $(52.8 \%)$ and 118 male respondents $(47.2 \%)$ participated in this research. According to the age structure, the largest number of respondents in the sample were aged 36-45 (31.2\%). Respondents who have completed master's and $\mathrm{PhD}$ studies represent a greater share in the sample $(51.6 \%)$. By origin, the majority of respondents are people who live outside the borders of the Republic of Serbia (72.4\%). The largest number of foreign respondents are from the following countries: the Republic of Croatia, Bosnia and Herzegovina, Greece, Romania, Macedonia, Italy, Slovenia, while a significantly smaller number of respondents are from other countries such as France, Russia, Poland, Bulgaria, China, etc. (Table 1). 
Table 1: Socio-demographic characteristics of the respondents $(n=250)$

\begin{tabular}{|c|c|c|c|c|}
\hline Variables & $\mathrm{n}$ & $\%$ & $\mathbf{M}$ & SD \\
\hline Gender & & & \multirow{3}{*}{1.53} & \multirow{3}{*}{.500} \\
\hline Male & 118 & 47.2 & & \\
\hline Female & 132 & 52.8 & & \\
\hline \multicolumn{5}{|l|}{ Age } \\
\hline $18-25$ & 45 & 18.0 & \multirow{6}{*}{2.74} & \multirow{6}{*}{1.229} \\
\hline $26-35$ & 64 & 25.6 & & \\
\hline $36-45$ & 78 & 31.2 & & \\
\hline $46-55$ & 41 & 16.4 & & \\
\hline $56-65$ & 18 & 7.2 & & \\
\hline$>66$ & 4 & 1.6 & & \\
\hline \multicolumn{5}{|l|}{ Level of education } \\
\hline Primary school & 3 & 1.2 & \multirow{6}{*}{4.30} & \multirow{6}{*}{.932} \\
\hline High school graduate & 19 & 7.6 & & \\
\hline Vocational degree & 7 & 2.8 & & \\
\hline Bachelor's degree & 92 & 36.8 & & \\
\hline Master $/ \mathrm{PhD}$ & 129 & 51.6 & & \\
\hline \multicolumn{3}{|l|}{ Origin } & & \\
\hline Domestic tourists & 69 & 27.6 & \multirow{2}{*}{1.72} & \multirow{2}{*}{.448} \\
\hline Foreign tourists & 181 & 72.4 & & \\
\hline Total & 250 & 100,0 & & \\
\hline
\end{tabular}

n-number of respodents; \%-percentage; $M$ - arithmetic mean; SD-standard deviation

Source: Author's calculation based on SPSS 26.0

Table 2 shows the answers of the respondents to the questions related to the organizing of their travel and staying in Belgrade. When asked about the length of stay, $46.4 \%$ of the respondents stated that they were staying in Belgrade for 2-3 days, while the most represented respondents in the sample are the ones who had visited Belgrade 6 or more times $(40.4 \%)$. The largest number of respondents made a decision to visit Belgrade based on previous experience (28.0\%); via information from the Internet $(27.2 \%)$ and based on the recommendations of relatives and/or friends $(26.4 \%)$. The answers of the respondents who stated that Belgrade had been chosen as the destination of their travel by the institution which organized the conference they were attending, an institution/company, fair organizers or that the basis for staying in the city is an invitation to attend a certain event, are classified under option Other. When asked about the organization of the travel, $74.0 \%$ of the respondents stated that they had organized their travel completely independently. Respondents who are classified under the option Other stated that their travel had been organized by the company in which they were employed.

Table 2: Characteristics related to respondents' travel and stay in Belgrade $(n=250)$

\begin{tabular}{|l|c|c|c|c|}
\hline Variables & $\mathbf{n}$ & $\mathbf{\%}$ & M & SD \\
\hline Length of stay & & & \multirow{3}{*}{3.61} & \multirow{2}{*}{1.279} \\
\cline { 1 - 3 } Less than a day & 7 & 2.8 & \\
\hline One day & 26 & 10.4 & & \\
\hline
\end{tabular}




\begin{tabular}{|c|c|c|c|c|}
\hline 2-3 days & 116 & 46.4 & & \\
\hline 4-5 days & 44 & 17.6 & & \\
\hline 6-7 days & 22 & 8.8 & & \\
\hline Longer than 7 days & 35 & 14.0 & & \\
\hline Number of visits & & & & \\
\hline Once & 68 & 27.2 & \multirow{5}{*}{2.66} & \multirow{5}{*}{1.258} \\
\hline $2-3$ times & 50 & 20.0 & & \\
\hline $4-5$ times & 31 & 12.4 & & \\
\hline 6 and more times & 101 & 40.4 & & \\
\hline \multicolumn{3}{|l|}{ Decision to visit Belgrade } & & \\
\hline Based on the recommendation of relatives/friends & 66 & 26.4 & \multirow{7}{*}{2.80} & \multirow{7}{*}{1.626} \\
\hline Over the Internet & 68 & 27.2 & & \\
\hline Through the offer of a travel agency & 21 & 8.4 & & \\
\hline Based on previous experience & 70 & 28.0 & & \\
\hline Through tourist information documentation & 7 & 2.8 & & \\
\hline Through the media & 7 & 2.8 & & \\
\hline Other & 11 & 4.4 & & \\
\hline \multicolumn{3}{|l|}{ Organization of travel to Belgrade } & \multirow{5}{*}{1.44} & \multirow{5}{*}{.790} \\
\hline Independently & 185 & 74.0 & & \\
\hline By a travel agency & 24 & 9.6 & & \\
\hline By the company in which respondents work & 38 & 15.2 & & \\
\hline Other & 3 & 1.2 & & \\
\hline Total & 250 & 100,0 & & \\
\hline
\end{tabular}

Source: the author's calculation based on SPSS 26.0

Table 3 shows the results of the statistical analysis of the respondents' motives for staying in Belgrade. Within the conducted research, 14 potential motives for staying in Belgrade were defined. When coding the data, the motives for the stay of respondents in Belgrade were coded $(1=$ yes, $2=$ no $)$. Respondents were given the opportunity to choose one motive which was the main reason for staying in Belgrade. The most represented respondents in the sample were those who stayed in Belgrade for: business purposes $(21.2 \%)$, scientific conferences $(15.2 \%)$, sightseeing $(14.0 \%)$, visiting relatives and/or friends (13.6\%) and nightlife (10.4\%).

Table 3: The main respondents' motives for staying in Belgrade $(n=250)$

\begin{tabular}{|l|c|c|}
\hline Motives for staying in Belgrade & $\mathbf{n}$ & $\mathbf{\%}$ \\
\hline Passive rest and relaxation & 12 & 4.8 \\
\hline Nightlife & 26 & 10.4 \\
\hline New experiences & 19 & 7.6 \\
\hline Sport and recreation & 6 & 2.4 \\
\hline Visiting relatives and/or friends & 34 & 13.6 \\
\hline Attendance at cultural events & 5 & 2.0 \\
\hline Attendance at sporting events & 3 & 1.2 \\
\hline Shopping & 5 & 2.0 \\
\hline Sightseeing & 35 & 14.0 \\
\hline
\end{tabular}




\begin{tabular}{|l|c|c|}
\hline Scientific conferences & 38 & 15.2 \\
\hline Business purposes & 53 & 21.2 \\
\hline Visit to museums, galleries, theatres, etc. & 8 & 3.2 \\
\hline Religious motives & 2 & .8 \\
\hline Tasting gastronomy and beverages & 4 & 1.6 \\
\hline Total & $\mathbf{2 5 0}$ & $\mathbf{1 0 0 , 0}$ \\
\hline
\end{tabular}

$n$ - number of respodents; \% - percentage;

Source: the author's calculation based on SPSS 26.0

\subsection{Results of the t-test of by gender and origin of respondents}

T-test of independent samples was used with aim to compare the values of the arithmetic mean of the answers between male and female respondents about the motives for staying in Belgrade. Out of a total of 14 motives, it has been found that there are statistically significant differences between respondents of different gender for one motive, which refers to Sightseeing at significance level $\mathrm{p}<0.05$. This motive was rates with higher average scores by male respondents $(M=1.91)$ than by female respondents $(M=1.82)$ (Table 4).

Table 4: T-test of independent samples according to the gender

\begin{tabular}{|l|c|c|c|}
\hline \multirow{2}{*}{ Motives } & \multicolumn{2}{|c|}{ Arithmetic mean } & \multirow{2}{*}{$\begin{array}{c}\text { t- } \\
\text { test }\end{array}$} \\
\cline { 2 - 3 } & Male (n=118) & Female (n=132) & .056 \\
\hline Passive rest and relaxation & 1.92 & 1.98 & .264 \\
\hline Nightlife & 1.87 & 1.92 & .988 \\
\hline New experiences & 1.92 & 1.92 & .085 \\
\hline Sport and recreation & 1.96 & 1.99 & .131 \\
\hline Visiting relatives and / or friends & 1.90 & 1.83 & .154 \\
\hline Attendance at cultural events & 1.97 & 1.99 & .499 \\
\hline Attendance at sporting events & 1.98 & 1.99 & .564 \\
\hline Shopping & 1.97 & 1.98 & $.041^{*}$ \\
\hline Sightseeing & 1.91 & 1.82 & .285 \\
\hline Scientific conferences & 1.82 & 1.87 & .534 \\
\hline Business purposes & 1.81 & 1.77 & .192 \\
\hline Visit to museums, galleries, theatres, etc. & 1.98 & 1.95 & .937 \\
\hline Religious motives & 1.99 & 1.99 & .372 \\
\hline Tasting gastronomy and beverages & 1.99 & 1.98 & \\
\hline
\end{tabular}

$* \mathrm{p}<0.05$

Source: the author's calculation based on SPSS 26.0

Applying the t-test of independent samples, the existence of statistically significant differences between respondents of different origin were determined for 4 out of the 14 analysed motives: New experiences; Sport and recreation; Visiting relatives and/or friends and Scientific conferences.

Table 5: T-test of independent samples according to the origin 


\begin{tabular}{|l|c|c|c|}
\hline \multirow{2}{*}{ Motives } & \multicolumn{2}{|c|}{ Arithmetic mean } & \multirow{2}{*}{ t-test } \\
\cline { 2 - 3 } & $\begin{array}{c}\text { Domestic } \\
\text { tourists } \\
\text { (n=68) }\end{array}$ & $\begin{array}{c}\text { Foreign } \\
\text { tourists } \\
\text { (n=181) }\end{array}$ & \\
\hline Passive rest and relaxation & 1.97 & 1.94 & .387 \\
\hline Nightlife & 1.93 & 1.88 & .272 \\
\hline New experiences & 1.99 & 1.90 & $.002^{*}$ \\
\hline Sport and recreation & 2.00 & 1.97 & $.014^{*}$ \\
\hline Visiting relatives and / or friends & 1.68 & 1.93 & $000^{*}$ \\
\hline Attendance at cultural events & 1.94 & 1.99 & .073 \\
\hline Attendance at sporting events & 2.00 & 1.98 & .083 \\
\hline Shopping & 1.96 & 1.99 & .215 \\
\hline Sightseeing & 1.84 & 1.87 & .587 \\
\hline Scientific conferences & 1.93 & 1.82 & $.011 *$ \\
\hline Business purposes & 1.81 & 1.78 & .575 \\
\hline Visit to museums, galleries, theaters, etc. & 1.97 & 1.97 & .868 \\
\hline Religious motives & 2.00 & 1.99 & .383 \\
\hline Tasting gastronomy and beverages & 1.99 & 1.98 & .907 \\
\hline
\end{tabular}

${ }^{*} \mathrm{p}<0.05$

\section{Source: the author's calculation based on SPSS 26.0}

By analysing the obtained results of the t-test, it can be concluded that statistically significant differences are present for the stated motives of the stay of respondents in Belgrade at significance level $\mathrm{p}<0.05$. If we observe the average scores of the tourists' motives for staying in Belgrade according to their origin, higher average scores for the motives of New experiences $(\mathrm{M}=1.99)$; Sport and recreation $(\mathrm{M}=2.00)$ and Scientific conferences $(\mathrm{M}=1.93)$ were given by respondents from the territory of the Republic of Serbia. Respondents of foreign origin gave the highest average scores for the motive Visiting relatives and/or friends $(\mathrm{M}=1.93)$ (Table 5).

\subsection{Results of one-factor analysis of variance (ANOVA)}

One-factor analysis of variance (ANOVA) was applied with the aim to examine the existence of statistically significant differences between the motives for staying in Belgrade depending on socio-demographic characteristics of respondents (education and age), which are defined as independent variables. Dependent variables are the tourists' motives for staying in Belgrade. In addition to ANOVA, the Tukey post hoc test was used in order to determine among which groups do exist statistically significant differences in terms of analyzed variables. 
Table 6: ANOVA according to education

\begin{tabular}{|c|c|c|c|c|c|c|c|}
\hline \multirow[b]{2}{*}{ Motives } & \multicolumn{5}{|c|}{ Middle value } & \multirow[b]{2}{*}{$\mathbf{F}$} & \multirow[b]{2}{*}{$\mathbf{p}$} \\
\hline & $\begin{array}{c}\text { group 1 } \\
\text { (Primary } \\
\text { school) }\end{array}$ & $\begin{array}{c}\text { group } 2 \\
\text { (High school } \\
\text { graduate) }\end{array}$ & \begin{tabular}{|c|} 
group 3 \\
(Vocational \\
degree)
\end{tabular} & \begin{tabular}{|c|} 
group 4 \\
(Bachelor's \\
degree)
\end{tabular} & $\begin{array}{c}\text { group } 5 \\
\text { (Master } \\
\text { /PhD) }\end{array}$ & & \\
\hline $\begin{array}{l}\text { Passive rest and } \\
\text { relaxation }\end{array}$ & 2.00 & 2.00 & 1.86 & 1.97 & 1.94 & .874 & .480 \\
\hline Nightlife & 1.67 & 2.00 & 1.86 & 1.85 & 1.92 & 1.836 & .123 \\
\hline New experiences & 2.00 & 1.84 & 1.86 & 1.95 & 1.92 & .775 & .542 \\
\hline $\begin{array}{l}\text { Sport and } \\
\text { recreation }\end{array}$ & 2.00 & 2.00 & 1.86 & 1.95 & 2.00 & 2.967 & $.020 *$ \\
\hline $\begin{array}{l}\text { Visiting relatives } \\
\text { and/or } \\
\text { friends }\end{array}$ & 2.00 & 1.84 & 2.00 & 1.82 & 1.89 & 1.083 & .365 \\
\hline $\begin{array}{l}\text { Attendance at } \\
\text { cultural } \\
\text { events }\end{array}$ & 2.00 & 1.95 & 1.86 & 1.99 & 1.98 & 1.767 & .136 \\
\hline $\begin{array}{l}\text { Attendance at } \\
\text { sporting events }\end{array}$ & 2.00 & 1.95 & 2.00 & 2.00 & 1.98 & 1.001 & .408 \\
\hline Shopping & 2.00 & 2.00 & 2.00 & 1.98 & 1.98 & .166 & .955 \\
\hline Sightseeing & 2.00 & 1.79 & 2.00 & 1.79 & 1.91 & 2.066 & .086 \\
\hline $\begin{array}{l}\text { Scientific } \\
\text { conferences }\end{array}$ & 2.00 & 1.95 & 2.00 & 1.96 & 1.74 & 6.040 & $.000 *$ \\
\hline Business reasons & 1.33 & 1.79 & 1.71 & 1.79 & 1.80 & 1.006 & .405 \\
\hline $\begin{array}{l}\text { Visit to museums, } \\
\text { galleries, theaters, } \\
\text { etc. }\end{array}$ & 2.00 & 1.95 & 2.00 & 1.99 & 1.95 & .692 & .598 \\
\hline Religious motives & 2.00 & 1.95 & 2.00 & 2.00 & 1.99 & 1.402 & .234 \\
\hline $\begin{array}{l}\text { Tasting } \\
\text { gastronomy and } \\
\text { beverages }\end{array}$ & 2.00 & 2.00 & 2.00 & 1.98 & 1.98 & .164 & .957 \\
\hline
\end{tabular}

*. The mean difference is significant at the 0.05 level.

Source: the author's calculation based on SPSS 26.0

Applying ANOVA, it was found that there are statistically significant differences between respondents of different education for 2 out of 14 motives, namely Sport and recreation $(\mathrm{F}=2,967 ; \mathrm{p}=.020)$ and Scientific conferences $(\mathrm{F}=6,040 ; \mathrm{p}=.000)$ (Table 6$)$. Although the existence of statistically significant differences were found, the difference between the mean values of the analysed groups was extremely small for the motive Sport and recreation. The results of the Tukey post hoc showed that there are statistically significant differences for the motive Scientific conference between the respondents who have bachelor's degrees and respondents with the highest level of education $($ Master/PhD) $(\mathrm{p}=.000)$. 
Table 7:ANOVA according to age

\begin{tabular}{|c|c|c|c|c|c|c|c|c|}
\hline \multirow[b]{2}{*}{ Motives } & \multicolumn{6}{|c|}{ Middle value } & \multirow[b]{2}{*}{$\mathbf{F}$} & \multirow[b]{2}{*}{$\mathbf{p}$} \\
\hline & $\begin{array}{l}\text { group } 1 \\
(18-25)\end{array}$ & $\begin{array}{l}\text { group } 2 \\
(26-35)\end{array}$ & $\begin{array}{l}\text { group } 3 \\
(36-45)\end{array}$ & $\begin{array}{l}\text { group } 4 \\
(46-55)\end{array}$ & $\begin{array}{l}\text { group } 5 \\
(56-65)\end{array}$ & $\begin{array}{c}\text { group } 6 \\
(>66)\end{array}$ & & \\
\hline $\begin{array}{l}\text { Passive rest } \\
\text { and relaxation }\end{array}$ & 1.93 & 1.95 & 1.96 & 1.93 & 2.00 & 2.00 & .429 & .828 \\
\hline Nightlife & 1.91 & 1.77 & 1.94 & 1.95 & 2.00 & 2.00 & 3.563 & $.004 *$ \\
\hline $\begin{array}{l}\text { New } \\
\text { experiences }\end{array}$ & 1.91 & 1.92 & 1.92 & 1.95 & 1.89 & 2.00 & .233 & .948 \\
\hline $\begin{array}{l}\text { Sport and } \\
\text { recreation }\end{array}$ & 1.98 & 1.98 & 1.96 & 2.00 & 2.00 & 1.75 & 2.260 & $.049 *$ \\
\hline $\begin{array}{l}\text { Visiting } \\
\text { relatives and / } \\
\text { or friends }\end{array}$ & 1.67 & 1.86 & 1.94 & 1.90 & 1.94 & 2.00 & 4.357 & $.001 *$ \\
\hline $\begin{array}{l}\text { Attendance at } \\
\text { cultural events }\end{array}$ & 2.00 & 1.97 & 1.96 & 2.00 & 2.00 & 2.00 & .788 & .559 \\
\hline $\begin{array}{l}\text { Attendance at } \\
\text { sporting events }\end{array}$ & 1.98 & 2.00 & 1.97 & 2.00 & 2.00 & 2.00 & .625 & .681 \\
\hline Shopping & 2.00 & 1.97 & 1.99 & 2.00 & 1.89 & 2.00 & 2.050 & .072 \\
\hline Sightseeing & 1.84 & 1.91 & 1.82 & 1.88 & 1.83 & 2.00 & .614 & .689 \\
\hline $\begin{array}{l}\text { Scientific } \\
\text { conferences }\end{array}$ & 1.98 & 1.89 & 1.79 & 1.76 & 1.83 & 1.75 & 2.354 & $.041 *$ \\
\hline \begin{tabular}{|l} 
Business \\
reasons
\end{tabular} & 1.89 & 1.81 & 1.77 & 1.73 & 1.67 & 1.75 & 1.105 & .358 \\
\hline $\begin{array}{l}\text { Visit to } \\
\text { museums, } \\
\text { galleries, } \\
\text { theaters, etc. }\end{array}$ & 1.96 & 1.98 & 2.00 & 1.93 & 1.94 & 1.75 & 2.474 & $.033^{*}$ \\
\hline \begin{tabular}{|l|} 
Religious \\
motives
\end{tabular} & 2.00 & 1.98 & 1.99 & 2.00 & 2.00 & 2.00 & .308 & .908 \\
\hline $\begin{array}{l}\text { Tasting } \\
\text { gastronomy } \\
\text { and beverages }\end{array}$ & 1.96 & 2.00 & 1.99 & 1.98 & 2.00 & 2.00 & .782 & .563 \\
\hline
\end{tabular}

*. The mean difference is significant at the 0.05 level.

Source: Source: the author's calculation based on SPSS 26.0

The results of ANOVA have showed that there are statistically significant differences for 5 out of 14 motives for staying in Belgrade between respondents of different age: Nightlife $(\mathrm{F}=3.563 ; \mathrm{p}=.004)$; Sport and recreation $(\mathrm{F}=2.260 ; \mathrm{Sig}=.049)$; Visit to relatives and/or friends $(\mathrm{F}=4.357 ; \mathrm{p}=.001) ;$ Scientific conferences $(\mathrm{F}=2.354 ; \mathrm{p}=.041)$ and Visits to museums, galleries, theatres, etc. $(\mathrm{F}=2.474 ; \mathrm{p}=.033)$ (Table 7). The results of Tukey post hoc test showed a statistically significant difference for the following groups of respondents:

- Nightlife - a statistically significant difference was found between: respondents aged $26-35$ and $36-45(\mathrm{p}=.011)$; respondents aged $26-35$ and $46-55$ years; $(\mathrm{p}=$ $.025)$ and respondents aged 26-35 and 56-65 $(\mathrm{p}=.041)$. 
- Sport and recreation - a statistically significant difference was found between: respondents aged $18-25$ and 66 and older $(p=.049)$; respondents aged $46-55$ and 66 and older $(\mathrm{p}=.022)$ and respondents aged 56-65 and 66 and older $(\mathrm{p}=.036)$.

- Visit to relatives and/or friends - a statistically significant difference was found between: respondents aged 18-25 and 26-35 ( $\mathrm{p}=.037)$; respondents aged 18-25 and 36-45 $(\mathrm{p}=.000)$; respondents aged 18-25 and 46-55 $(\mathrm{p}=.015)$ and respondents aged $18-25$ and $46-55(\mathrm{p}=.035)$.

- Scientific conferences - a statistically significant difference was found between respondents aged $18-25$ and $46-55(\mathrm{p}=.047)$.

- Visit to museums, galleries, theatres, etc. - The difference between the mean values for this motive is very small.

\section{Conclusion}

The research subject of this paper is the motivation of tourists for staying in the City of Belgrade. Based on the theoretical analysis of previous scientific papers on this topic, an appropriate methodology has been defined and applied with the aim of drawing conclusions about the motives of tourists to stay in Belgrade and the existence of statistically significant differences between the motives of tourists depending on their socio-demographic characteristics. The results of the descriptive statistical analysis have confirmed that tourists stay in Belgrade due to various motives, among which the following stand out: business reasons, scientific conferences, visits to relatives and/or friends, sightseeing and nightlife. The results of this study showed statistically significant differences for a very small number of motives for tourists staying in Belgrade. When it comes to gender, there are statistically significant differences for the motive Sightseeing where male tourists rated this motive with a higher average score compared to female tourists. Depending on the origin of tourists, the following motives for staying in Belgrade were highlighted: New experiences; Sport and recreation; Visiting relatives and/or friends, and Scientific conferences. If we look at the average ratings of the motives of tourists' stay in Belgrade according to their origin, higher average ratings for the motives of New experiences, Sports and recreation, and Scientific conferences were given by respondents from the territory of the Republic of Serbia. Respondents of foreign origin gave the highest average score for the motive Visiting relatives and/or friends. The results of the research showed the existence of statistically significant differences between the respondents with a bachelor's degree and the respondents with the highest level of education (Master / $\mathrm{PhD}$ ) for the motive of Scientific conferences. When it comes to age, it was determined that there are statistically significant differences for the motives Nightlife, Sport and recreation, Visits to relatives and/or friends, Scientific conferences, and Visit to museums, galleries, theatres, etc. mostly among tourists who belong to the category of younger tourists (18-25 and 26-35) and tourists who belong to the category of middle-aged and older (46-55, 56-65 and 66 and older). The results of this research have a scientific contribution, which is reflected in the theoretical analysis of other studies with the same subject of research, but also the application of theoretical knowledge in the preparation and realization of empirical research. Also there is a very small number of such studies on the tourists' motives for staying in Belgrade. The 
practical contribution refers to the fact that the research results can be used in order to define guidelines to improve the urban tourism offer in Belgrade as well as to identify key segments of tourists visiting this city and focus on meeting their needs. The limitations of this research relate to giving tourists the opportunity to choose only one motive for which they most often stayed in Belgrade. In future research, the degree of significance of all motives for the stay of tourists in the capital of our country should be analysed. Future studies should also be extended to other cities in the Republic of Serbia, which have the potential to become recognizable urban tourism destinations (Novi Sad, Niš, and Kragujevac).

\section{References}

Ashworth, G. J., \& Page, J. S. (2011). Urban tourism research: Recent progress and current paradoxes. Tourism Management, 32(1), 1-15. Doi: https://doi.org/10.1016/j.tourman.2010.02.002

Balińska, A. (2020). City break as a form of urban tourism. Zeszyty Naukowe Małopolskiej Wyższej Szkoły Ekonomicznej w Tarnowie, 46(2), 85-95.

Blank, U., \& Petkovich, M. (1980). The metropolitan area: a multifaceted travel destination complex. In: D. Hawkins, E. Shafer \& J. Ravelstad, J. (Eds.) Tourism Planning and Development (pp. 393-405). Washington: George Washington University.

Blank, U., \& Petkovich, M. (1987). Research on urban tourism destinations. In: JR. NB. Ritchie \& C. Goeldner (Eds). Travel, Tourism and Hospitality Research: A Handbook for Managers and Researchers. (pp. 165-177). New York: John Wiley.

Blešić, I., Wallranbestein, K., \& Dević, M. (2008). Motivation of Novi Sad (Vojvodina, Serbia) visitors out of the tourist season. Geographica Pannonica, 12, 45-52. Doi: https://doi.org/10.5937/GeoPan0801045B

Božić S., Kennell, J., Vujičić, M. D., \& Jovanović, T. (2017). Urban tourist motivations: why visit Ljubljana?. International Journal of Tourism Cities, 3(4), 382-398. Doi: https://doi.org/10.1108/IJTC-03-2017-0012

Crompton, J. L. (1979). Motivations for pleasure vacation. Annals of Tourism Research, 6(4), 408-424. Doi: https://doi.org/10.1016/0160-7383(79)90004-5

Dann, G. M. (1977). Anomie, ego-enhancement and tourism. Annals of Tourism Research, 4(4), 184-194. Doi: https://doi.org/10.1016/0160-7383(77)90037-8

Dann, G. M. (1981). Tourism motivations: An appraisal. Annals of Tourism Research, 8(2): 187-219. Doi: https://doi.org/10.1016/0160-7383(81)90082-7

Demirović, D., Cimbaljević, M., \& Vujko, A. (2018). Religious sites and events as resources for tourism development in cities: Case study: Novi Bečej. Menadžment $u$ hotelijerstvu $i$ turizmu - Hotel and tourism management,6(1), 63-71. Doi: https://doi.org/10.5937/menhottur1801063D 
Devesa, M., Laguna, M., \& Palacios, A. (2010). The role of motivation in visitor satisfaction: Empirical evidence in rural tourism. Tourism Management, 31(4), 547-552. Doi: https://doi.org/10.1016/j.tourman.2009.06.006

Dunne, G., Buckley, J., \& Flanagan, S. (2007) City break motivation - The case of Dublin, a successful national capital. Journal of Travel and Tourism Marketing, 22(3/4), 95-107. Doi: https://doi.org/10.1300/J073v22n03 08

Dunne, G. (2009). Motivation and decision making in city break travel: The case of Dublin. Saarbrucken, Germany: VDM Publishing.

Filipović, N. (2018). Intangible cultural heritage as a motive for choosing the tourist destination Aranđelovac. Menadžment u hotelijerstvu $i$ turizmu - Hotel and tourism management, 6(1), 53 - 62. Doi: https://doi.org/10.5937/menhottur1801053F

Füller, H., \& Michel, N. (2014). Stop Being a Tourist!' New Dynamics of Urban Tourism in Berlin-Kreuzberg. International Journal of Urban and Regional Research, 38(4), 1304-1318. Doi:https://doi.org/10.1111/1468-2427.12124

Jansen-Verbeke, M. (1986). Inner-city tourism: resources, tourists and promoters. Annals of Tourism Research, 13(1), 79-100. Doi: https://doi.org/10.1016/0160-7383(86)90058-7

Iso-Ahola, S. E. (1982). Toward a Social Psychological Theory of Tourism Motivation. Annals of Tourism Research, 9(2), 256-262. Doi: https://doi.org/10.1016/0160$\underline{7383(82) 90049-4}$

Lakićević, M., \& Sagić, Z. (2019). Accommodation capacities and their utilization in the function of tourism development: Case of Ivanjica. Ekonomika, 65(3), 77-88. Doi: https://doi.org/10.5937/ekonomika1903077L

López-Guzmán, T., Pérez Gálvez, J. C., \& Muñoz-Fernández, G. A. (2018). Satisfaction, motivation, loyalty and segmentation of tourists in World Heritage cities. Revista de $\begin{array}{lllll}\text { Turismo } y & \text { Patrimonio } \quad \text { Cultural, } & \text { 16(1), } & \text { Doi: }\end{array}$ https://doi.org/10.25145/j.pasos.2018.16.005

Page, S.J. (1995). Urban Tourism.London: Routledge.

Pearce, D. (2001). An Integrative Framework for Urban Tourism Research. Annals of Tourism Research, 28(4), 926-946. Doi: https://doi.org/10.1016/S0160-7383(00)00082-7

Podovac, M. (2017). City break travel as a factor of tourism industry competitiveness. 2nd International scientific conference Tourism in Function of Development of the Republic of Serbia - Tourism product as a factor of competitiveness of the Serbian economy and experiences of other countries, (Eds): Cvijanović et al., University of Kragujevac - Faculty of Hotel Management and Tourism in Vrnjačka Banja, Serbia, Vrnjačka Banja, 1-3 June, 2017, 659-678.

Podovac, M. (2016). Gradski turizam u funkciji konkurentnosti Republike Srbije, [Urban tourism in the function of competitiveness of the Republic of Serbia]. 1stInternational Thematic Monograph Modern management tools and economy of tourism sector in present era: (Eds): Bevanda, V., Štetić, S.Association of Economists and Managers of the Balkans ; Ohrid : Faculty of Tourism and Hospitality, 161-177. 
Podovac, M. (2019). Tourist resources of the city of Niš in the function of its development as an urban tourist destination. BizInfo, 10(2), 139-153. Doi: https://doi.org/10.5937/bizinfo1902139P

Podovac, M., Drpić, D., \& Milojica, V. (2020). Analysis of tourism supply of the city of Zagreb and perspectives of its future development. Menadžment u hotelijerstvu i turizmu Hotel and tourism management, 8(1), 89-99. Doi: https://doi.org/10.5937/menhottur2001089P

Pyo, S., Mihalik, J. B., \& Uysal, M. (1989). Attraction attributes and motivations: a canonical correlation analysis. Annals of Tourism Research, 16(2), 277-282. Doi: https://doi.org/10.1016/0160-7383(89)90077-7

Ramires, A., Brandao, F. \& Sousa, A. C. (2018). Motivation-based cluster analysis of international tourists visiting a World Heritage City: The case of Porto, Portugal. Journal of Destination Marketing \& Management, 8, 49-60. Doi: https://doi.org/10.1016/j.jdmm.2016.12.001

Remoaldo, P., Vareiro, L., Ribeiro, J. C. \& Marques, V. (2017). Tourists' motivation toward visiting a world heritage site: The case of Guimarães. CICS-Publicações/eBooks, 99-121.

Sančanin, B., Perić, G. \& Stojiljković, M. (2019). Cultural-historical resources as initiators of tourism development in Sremski Karlovci. Menadžment u hotelijerstvu i turizmu - Hotel and tourism management, 7(2), 77 - 85. Doi: https://doi.org/10.5937/menhottur1902077S

Statistical Office of the Republic of Serbia (2020). Tourist turnover - December 2019. Retrieved from: https://publikacije.stat.gov.rs/G2020/Pdf/G20201020.pdf (Accessed: July 17, 2020).

Todorović, N., \& Jovičić, D. (2016). Motivational factors of youth tourists visiting Belgrade. Journal of the Geographical Institute "Jovan Cvijić", 66(2), 273-289. Doi: https://doi.org/10.2298/IJGI1602273T

Tomić, S., Leković, K., Eskerod, P., \& Zedlacher, E. (2020). Profile of rural tourism consumers in Serbia and Austria. Anali Ekonomskog Fakulteta u Subotici, 56(44), 81-95. Doi: https://doi.org/10.5937/AnEkSub2044081T

Tournois, L., \& Đerić, G. (2019). Evaluating urban residents' attitudes towards tourism development in Belgrade (Serbia). Current Issues in Tourism, 22(14), 1670-1678. Doi: https://doi.org/10.1080/13683500.2018.1465030

Vujičić, M. D., Stamenković, I., Stankov, U., Kovačić, S., Vasiljević, Đ. A., \& PopovLocke, J. (2020). What will prevail within city break travel, motivation or demotivation?: Case study of Novi Sad, Vojvodina, Serbia. Geographica Pannonica, 24(1), 42-55. Doi: https://doi.org/10.5937/gp24-22613

Yoon, Y., \& Uysal, M. (2005). An examinationof the effects of motivation and satisfaction on destination loyalty: a structural model. Tourism Management, 26(1), 45-56. Doi: https://doi.org/10.1016/j.tourman.2003.08.016 
